\title{
"ANALYSIS ON RAILWAY SLEEPERS MANUFACTURED FROM POLYMERS AND IRON SLAG"
}

\author{
Ahmed Abdelmoamen Khalil ${ }^{1}$, Heba Mahmoud Bakry ${ }^{2}$, Hany SobhyRiad ${ }^{3}$ \\ and Ali SaadShnour ${ }^{4}$ \\ ${ }^{1}$ Civil Eng. department, Shoubra Faculty of Eng., Benha University, Cairo, Egypt. \\ ${ }^{2}$ Civil Eng. department, Shoubra Faculty of Engineering, Benha University, Cairo, Egypt. \\ ${ }^{3}$ Civil Engineering department, Faculty of Engineering, Ain Shams University, Cairo, Egypt. \\ ${ }^{4}$ Civil Eng. department, Shoubra Faculty of Engineering, Benha University, Cairo, Egypt.
}

\begin{abstract}
Timber is the most commonly used material for railway sleepers. However, as a sleeper material deteriorates with time, it becomes so expensive and needs suitable replacement. There are also now various environmental concerns regarding the use and disposal of chemically-impregnated timber sleepers. Composite sleepers have become great replacement of existing timber ones. In this paper, a review of advantages and disadvantages of existing timber sleepers are presented as well as conventional methods in analysis and design of railway sleepers. Trials and proportions of proposed composite mixture using polymers and iron slag are portrayed. Mechanical and physical testing has been carried out to determine the important properties of the new selected mixture; hence results are compared with the recommendations of the international railway standards. It is found that the testing results are larger than the recommended values. Thus; it is concluded that the tested composite mixture is effective and adequate to be used in manufacture of railway sleepers. Selection of the optimal sleeper dimensions by Evaluation of 21 suggested models of sleeper with different dimensions is also presented.
\end{abstract}

\section{KEYWORDS: Railway Sleepers, fiber composites, Iron Slag, mechanical testing.}

\section{INTRODUCTION}

Railway sleeper is one of the most important components of the railway system. It is a beam under the rails as shown in Fig.1[1] to support the track and keep the required gauge width. It is also responsible for distribution and transfer of load to ballast section, and prevent any lateral and longitudinal movement of rail system [2].

Timber sleepers which are used in Egyptian National Railways (ENR) are manufactured from one of three different types; Beach, Azobe, or Oak woods [3]. The main advantage of timber sleepers is their adaptability. They can be fitted with all types of railway track. Timber sleepers are workable, easy to handle, easy to replace and needs no complex assembly equipment. Thus, local problem sites can be repaired or replaced without the need for outside support which is represented in either manpower or equipment. It is only appropriate for low speed lines with the speed limit $160 \mathrm{~km} / \mathrm{h}$ [4]. In addition, it can absorb severe impact with limited damage [5].

Timber sleeper has an excellent electrical isolation, an important factor for track signaling which cannot be matched by other alternative sleeper materials except maybe by plastics or fiber composites[6]. 
The main disadvantage in using timber sleepers is its high cost and their exposure to mechanical and biological degradation leading to failure [7]. Fungal decay, end splitting and spike retention are most common failure modes in timber sleepers as shown in Figures 2.a [8]\& 2.b [7]. Timber sleepers were also attacked and damaged by thermites [7]. Cracking at fasteners positions can happen during handling or installation as shown in Fig. 2.c [9]. An alternative material for sleeper replacement to reduce maintenance cost and overcome problems encountered using timber sleepers is therefore both desirable and necessary.

Fiber composites could be an ideal material for the development of railway sleepers. This composite material typically comprises of strong fibers embedded within a light polymer matrix offering high strength, lightweight, durability, good electrical insulating properties and low-life maintenance costs which is a suitable material for the replacement of deteriorated timber sleepers [10].

The performance of a sleeper to resist lateral and longitudinal loading is relied on the sleeper's size, shape, surface geometry, weight, and spacing [11].Current practices concerning the analysis and design of sleepers include three steps as following [12]: a) considering a dynamic coefficient; b) estimation of vertical rail seat load; c) assuming a stress distribution pattern under the sleeper and applying vertical static equilibrium to a structural model of the sleeper.

Researchers all over the world have recommended several formulae and values for the calculation of the dynamic coefficient. Table 1 presents a summary of the main recommendations for the dynamic coefficient factors [12]. The exact magnitude of the load applied to each rail seat depends upon numerous parameters including the rail weight, the sleeper spacing, the track modulus per rail, the amount of play between the rail and sleeper, and the amount of play between the sleeper and ballast [11]. Based on these considerations, various relations are proposed for the amount of rail-seat loads that are summarized in Table 2 .

The general approach for the calculation of the contact pressure beneath the rail seat is to assume a uniform contact, pressure distribution over the assumed effective area of the sleeper. This assumption is made in order to facilitate the ease of calculations. While maximum allowable pressure between the sleeper and the ballast can be calculated according to AREA formula [13] as follow:

\section{$\frac{4 \boldsymbol{P} P \cdot \boldsymbol{F}}{\boldsymbol{B} \boldsymbol{I}}$}

$\mathbf{P}_{\mathbf{a}}=$

Where $\mathrm{P}=$ design wheel load $(\mathrm{kN})$ (i.e. static wheel load multiplied by the dynamic cofficient), DF $=$ the AREA distribution factor , B = breadth of sleeper $(\mathrm{m})$, and $l=$ total length of sleeper (m).

Bending stress at rail seat is calculated according to following equation [14]:

$\sigma_{\mathrm{ru}}=\frac{M_{r}}{Z}=3 * \mathrm{q}_{\mathrm{r}} *$

Where: $\mathrm{Z}$ (section modulus $)=\frac{B t^{\mathbf{2}}}{\mathbf{6}}, \mathrm{q}_{\mathrm{r}}=$ rail seat load $(\mathrm{KN}), l=$ total sleeper length $(\mathrm{m})$, $g=$ distance between rail centers $(\mathrm{m}), \mathrm{B}=$ sleeper width $(\mathrm{m}), \mathrm{t}=$ sleeper thickness $(\mathrm{m}), M_{r}=$ bending moment at rail seat which is calculated with different methods as shown in Table 3 . 
Bending stress at center of sleeper is calculated according to the following equation [14] by assuming uniform pressure distribution over the total sleeper length.

$\sigma_{\mathrm{c}}=\frac{M_{C}}{Z}=\frac{3}{2} * \mathrm{q}_{\mathrm{r}} *$

$M_{c}=$ bending moment at center of sleeper which is calculated with different methods as shown in Table 3.

\section{Experimental program \\ 2.1 Materials}

Recycled high density polyethylene (RHDPE), iron (blast furnace) slag [15], calcium carbonate $(\mathrm{CACO} 3)$ and polyester resin are used in addition to $\mathrm{E}$ glass fiber with different type and weight for getting a composite mixture which complies with universal standards.

\subsection{Mixture proportions}

The mixture proportions of the tested composite mixtures which are divided into four groups are given in Table 4.

\subsection{Mixing Stage}

A hand lay-up (HLU) technique was used to mix and cast the specimens. The solids constituents of the composite mixture, the recycled high density polyethylene, steel slag and calcium carbonate were dry mixed for about three minutes. The liquid part of the mixtures, the polyester resin, the styrene and cobalt were premixed then added to the solids. The wet mixing usually continued for another four minutesto achieve a uniform dispersion of mixture components. Before casting the mixture into the mold, MEKP was added and thoroughly stirred.

\subsection{Casting and Curing Stage}

The fiber-plastic molds were manufactured at private workshop. The molds were in the form of $100 \times 150 \times 150 \mathrm{~mm}$ cubes and $100 \times 100 \times 500 \mathrm{~mm}$ prisms as shown in Fig. 5 [15].Once the mixture had been mixed, the mixture was poured into the molds in three or four layers according to number of used fiber layers as shown in Fig. 6. Three cubes were taken from each mix (100x150x150 mm) and 2 flexure beams (100x100x500mm).

After casting stage, the specimens were stored in the laboratory. Then, after 24 hours, the specimens were demolded.

\section{Testing procedure}

Mechanical and physical tests were performed on composite specimens in accordance with the American Society for Testing and Materials (ASTM) standards.

3.1 Compressive strength

Compressive test perpendicular and parallel to grain of the specimens was performed following the (ASTM D 6108-97) standards[16] at Properties of Materials and Quality Control Lab, Shoubra Faculty of Engineering. 100 x 150 x150 mm cubical specimens were used for determination of compressive strength and Stress- strain relationship for composite mixes. The load was applied uniformly on the loading surface of the specimen at a constant cross head speed of $1 \mathrm{~mm} / \mathrm{min}$ till the failure. The test set-up for compressive test of the composite specimen is shown in Fig.7.

\subsection{Flexural strength (modulus of rupture)}

Flexural strength test was carried out on prismatic specimens of $100 \times 100 \times 500 \mathrm{~mm}$. The 4-point static bending test on composite specimens was performed in accordance with the ( ASTM D6109 -97) standards at Properties of Materials and Quality Control Lab, Shoubra Faculty of Engineering by the use of a $50 \mathrm{KN}$ manual hydraulic flexural machine as shown in Fig.8. The load was applied at the third and at the two-third points of the span of specimen with rate $3 \mathrm{~mm} / \mathrm{min}$. Schematic illustration of test set up is shown in Fig.9. The flexural strength in terms of modulus of rapture was calculated using the following equation:

$\mathrm{R}=\frac{P L}{b d^{2}}($ ASTM D6109 -97)[16] 
Where; $\mathrm{R}=$ Modulus of rapture $\left(\mathrm{N} / \mathrm{mm}^{2}\right), \mathrm{P}=$ Maximum (failure) load $(\mathrm{N}), \mathrm{L}=$ effective Length of the specimen $(\mathrm{mm}), \mathrm{b}=$ width of the specimen $(\mathrm{mm}), \mathrm{d}=$ depth of the specimen $(\mathrm{mm})$.

\subsection{Load - Deflection relationship}

To get Load -deflection relationship, the test was performed on mix S16 accordance with (ASTM D6109 -97) standards [16] at Researches and Building Center. The 4 - point static bending test was performed on composite beams as illustrated in Fig.10. The load was applied at the third and at the two-third points of the span of specimen with rate $3 \mathrm{~mm} / \mathrm{min}$. Stress and strain are computed by using the following formulae according to ASTM D6109 -97 standards to get modulus of elasticity flexure

Stress $=\left(\mathrm{P}_{2}-\mathrm{P}_{1}\right) * \mathrm{~L} / \mathrm{bd}^{2}$

Strain $(\mathrm{r})=4.7 *\left(\Delta_{2}-\Delta_{1}\right) / \mathrm{L}^{2}$

Modulus of elasticity $(\mathrm{E})=$ stress /strain

Where:

$\mathrm{P}=$ Maximum (failure) load $(\mathrm{N}), \mathrm{L}=$ effective Length of the specimen $(\mathrm{mm}), \mathrm{b}=$ width of the specimen $(\mathrm{mm}), \mathrm{d}=$ depth of the specimen $(\mathrm{mm}), \Delta=\operatorname{deflection}(\mathrm{mm})$

\subsection{Density and Specific Gravity Test}

This test was performed on four samples of mix S16 according to (ASTM D 6111-03) [16] at Railway Engineering Lab, Shoubra Faculty of Engineering. The four samples are illustrated in Fig.11. The specimen is weighed in air then weighed when immersed in distilled water at $23^{\circ} \mathrm{C}$ using a sinker and wire to hold the specimen completely submerged as required.

Density and Specific Gravity are calculated according to following equation:

- $\quad$ Specific gravity $=a /\lceil(a+w)-b\rceil(A S T M D$ 6111-03 $)$

$a=$ mass of specimen in air, $b=$ mass of specimen and sinker (if used) in water.

$\mathrm{W}=$ mass of totally immersed sinker if used and partially immersed wire

- Density $\left(\mathrm{kg} / \mathrm{m}^{3)}=(\right.$ specific gravity $) \times \rho_{\text {water }}$ Where: $\rho_{\text {water }}=997.6 \mathrm{Kg} / \mathrm{m}^{3}$

- Density $\left(\mathbf{k g} / \mathbf{m}^{3}\right)=$ (specific gravity) x (997.6)

\subsection{Coefficient of linear thermal expansion (CLTE) Test}

The test was carried out at Chemistry Administration on Ramses according to (ASTM D 696-03) [16] which covers temperatures between $-30^{\circ} \mathrm{C}$ and $30^{\circ} \mathrm{C}$. $25 * 25^{*} 150 \mathrm{~mm}$ specimen was used as shown in Fig.12. The Specimen is placed in a $-30^{\circ} \mathrm{C}\left(-22^{\circ} \mathrm{F}\right)$ constant temperature bath. After the specimen has reached a temperature of $-30^{\circ} \mathrm{C}$, the constant temperature bath is replaced by a $30^{\circ} \mathrm{C}\left(86^{\circ} \mathrm{F}\right)$ constant temperature bath. After the specimen has reached a temperature of $30^{\circ} \mathrm{C}$, the $30^{\circ} \mathrm{C}$ bath is replaced by the $-30^{\circ} \mathrm{C}$ bath. After the specimen has reached a temperature of $-30^{\circ} \mathrm{C}$, the specimen is removed and measured at room temperature. Test set up is shown in Fig. 14.

CLTE $(\alpha)$ is calculated using the formula: $\alpha=\Delta \mathrm{L} /\left(\mathrm{L}_{\mathrm{n}} * \Delta \mathrm{T}\right)(\mathrm{ASTM} \mathrm{D} 696-03)$

Where: $\Delta \mathrm{L}$ is the change in length of the specimen, $\mathrm{L}_{\mathrm{o}}$ is the original length of the specimen and $\Delta \mathrm{T}$ is the temperature change during the test.

\section{Results and Discussions}

The methodology of composite mix selection is based on economy and achieving both compressive and flexural strength that satisfies the recommendations of American Railway Engineering and Maintenance of way Association (AREMA) standards and Chicago Transit Authority (CTA) specifications [17]. AREMA standards and CTA specifications are presented in Table 5. 


\subsection{Compression test perpendicular to grain}

The reported values for both density and compressive strength of composite mixtures are presented in Table 6.

The results in Table (6) show that the compressive strength ranged from $23.70 \mathrm{MPa}$ to 32.08 $\mathrm{MPa}$. It is also concluded that all mixes have a value more than Chicago (CTA) specifications and AREMA standards which recommend that minimum compressive strength is $6.89,6.2$ $\mathrm{MPa}$. The optimum mix from all mixes is mix S16 that has a value of compressive strength much higher than recommended minimum values of Chicago (CTA) and AREMA standards. S16 has also lower cost of used materials which make it more economy than other mixes. The specimen tested under perpendicular compression to grain failed by formation of cracks appeared at the center of its side as illustrated in Fig.14.

\subsection{Stress- Strain relationship}

Figures from (15) to (24) illustrate the stress-strain curves of mixes containing different percentages of matrix, fillers and additives. The stress- strain curve and modulus of elasticity was measured on mixes S1, S2, S4, S4w, S5, S1-c, S8, S10, S4c and S16. The elasticity modulus was calculated from the slope of the initial portion of the compressive stress-strain relation curve. Compressive modulus of elasticity is shown in Table 7.

The stress-strain curve in Figures (15 to 24 ) shows that the composite mixtures behave almost linearly under compression at higher level of stress. With the continuous application of load, the composite material started to behave nonlinearly up to failure. A sudden drop in the stress level was observed at a strain between 4500 and 7000 micro strains. The sudden drop in the stress level could be due to the cracks which develop at the outer part of the composite sample. Shortly after the maximum compressive stress is reached, the crack width increased and the stress level dropped dramatically. The specimen failed with all the cracks occurring at the outer part of the sample. The failure strain was not measured for mix S4w. It is due to cracks that happened in the outer wrapped fiber which led to failure of attached strain gauge before specimen failure.

From stress- strain results, it is clear that the values of modulus of elasticity (Ec) which were calculated from the stress-strain curve by chord method ranged from $3427 \mathrm{MPa}$ to 10297 $\mathrm{MPa}$. The lower and higher values of modulus of elasticity (Ec) specified to the mix S5 and mix S2 respectively. It is concluded that all mixes have a value more than AREMA standards and Chicago (CTA) specifications which recommend that minimum modulus of elasticity is 1172.11 MPa. Mix S16 is preferred to be the proposed composite mixture. Because it combines with low materials cost and high value of elasticity modulus that is $8581 \mathrm{MPa}$ which is higher than a minimum recommended value of AREMA and Chicago (CTA) standards.

The results also indicated that the relationship of the stress-strain and strain values of the proposed mix S16 which are 5000 and 6000 micro strain are similar to the behavior of some wooden types.

\subsection{Flexural strength}

The reported values for flexural strength of composite mixtures are presented in Table 8 . Flexural load and strength were obtained for two specimens after the failure.

The flexure strength can be expressed in terms of modulus of rapture, where the maximum stress is at rapture. The results of flexure strength in Table 8 ranged from $22.07 \mathrm{MPa}$ to 10.95 $\mathrm{MPa}$. The higher value of flexure strength was recorded for the mix S16 and the lowest value of flexure strength was achieved by mix S4. Mix S16 was selected to be the optimum mixture. Because it has a highest value of flexure strength which is higher than minimum recommended values of AREMA standards and Chicago (CTA) specifications which are 13.7 $\mathrm{MPa}$ and 17.23 $\mathrm{MPa}$ respectively.

\subsection{Load - deflection relationship}

The reported values for maximum flexural load and modulus of elasticity of composite mixtures are presented in Table 13. Also, load - deflection curve is illustrated for mixes S161, S16-2 in Fig. 25. 
From Figure 25 , it is noted that the load of specimen S16-1and S16-2 increased linearly with deflection until a load of $22 \mathrm{KN}$ where a slight decrease in stiffness was observed after. It is due to the initiation of tensile cracks in the core of specimen at the constant moment region. Flexural cracks were observed at the bottom of specimen as shown in Fig.26. The specimen S16-1 failed at an applied load of around $56 \mathrm{KN}$ with a mid-span deflection $6 \mathrm{~mm}$. but specimen S16-2 failed at an applied load of around $54 \mathrm{KN}$ with a mid-span deflection 6 $\mathrm{mm}$. It can also be observed that the specimen S16 has an average flexural elasticity modulus of around 1519.82 MPa which is larger than recommended values of Chicago (CTA) and AREMA standards that are $1379,1172 \mathrm{MPa}$ respectively.

4.5 Compressive strength parallel to grain

The reported values for maximum compressive load parallel to grain of composite mixture S16 are presented in Table 9. Compressive load and strength were obtained for three specimens of S16 after the failure.

From table 9, it is clear that the specimen has a compressive strength value that is higher than 20.68 MPa which is a recommended minimum value of Chicago standards.

4.6 Density and specific gravity

Density and specific gravity results for four samples of mix S16 were obtained as shown in Table 10.

From specific gravity test results, it is concluded that density of proposed sleeper which is manufactured from mix S16 is $1314 \mathrm{Kg} / \mathrm{m}^{3}$. The weight of proposed sleeper meets or falls within the required weight - range specified for composite sleepers in AREMA-30 standard 「181.

4.7 Coefficient of linear thermal expansion

First trial, after the specimen has subiected to cold $\left(-30^{\circ} \mathrm{C}\right)-$ hot $(30)-$ cold $(-30)$ series of exposure conditions for 24 hours, no change in length was found.

Second trial, After the specimen has placed in $-30^{\circ} \mathrm{C}$ path for 30 hours then in $30 \mathrm{C}$ for 30 hours then $-30 \mathrm{C}$ for 30 hours, slightly change in length was occurred as shown in table 16 It is obviously that the specimen has a low coefficient of linear thermal expansion 2.3E-05 $\mathrm{mm} / \mathrm{mm} . \mathrm{C}^{\mathrm{o}}$ which less than recommended maximum values of AREMA and Chicago standards that is $13.5 \mathrm{E}-05$ and $12.6 \mathrm{E}-05$ respectively.

\section{Design of proposed sleeper}

Sleeper with $170 \mathrm{~mm}$ thickness, 230 $\mathrm{mm}$ width and $2600 \mathrm{~mm}$ length (T1) was used as a datum to reach to the optimum model which satisfies standards recommendations. In order to reach the optimum geometrical properties of a T1 sleeper, 21 suggested dimensions of T1 are evaluated as shown in Table 5-1.

For the analysis of the models, the following assumptions are taken into account:

- The maximum transferred load to the sleeper exactly under the wheel is $50 \%$ of the wheel load according to (three adjacent sleeper)[12] method.

- The design speed of trains is $120 \mathrm{Km} / \mathrm{hr}$.

- The dynamic factor $\varnothing$ which was calculated according to Schramm\& DB equation [12] is 1.388 .

- The axial load is considered to be 22.5 Tons.

- The concentrated load at each rail seat position according to (Three Adjacent Sleeper) method is $76.51 \mathrm{KN}$ : qr $=0.5 \times 1.388 \times 11250 \times 9.8=76.51 \mathrm{kN}$.

- The maximum contact pressure between sleeper and ballast was calculated from AREA

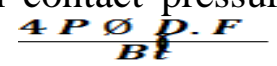

formula [13]: $\mathbf{P}_{\mathbf{a}}=$

- Positive Bending moment at rail seat was calculated according to Australian equation [14]:

$\mathrm{M}_{\mathrm{r}}=\mathrm{q}_{\mathrm{r}}\left(\frac{l-g}{\mathbf{8}}\right)$.

- Negative bending moment at center of sleeper was calculated according to Raymond's

equation [14]: $\operatorname{Mc}=\operatorname{qr}\left(\frac{2 g-l}{4}\right)$ 
- Bending stress at rail seat and center of sleeper were calculated according to formula $\sigma_{\mathrm{ru}} \mathrm{or} \sigma_{\mathrm{c}}$ $=[14]$

- Minimum thickness at rail seat was calculated according to AREA method [11]:

$$
\mathrm{T}^{2}{ }_{\min }=\frac{\mathbf{3 l} *(l-g) * \text { Pall }}{8 * 1000 * \sigma \mathbf{r u} * \mathbf{2} \mathbf{2}} \text { where } \mathrm{P}_{\text {all }}=\text { maximum allowable pressure between ballast }
$$
and sleeper which is ranged from $450 \mathrm{KPa}$ to $590 \mathrm{KPa}$ according to AREA recommendations [13], F2 is safety factor depending on track maintenance which equal 2 according to AREA recommendations.

- Minimum thickness at center of sleeper was calculated from AREA equation [11]: $\mathrm{T}^{2}$ min $=$ $3 l *(2 g-l) * P a l l$

$4 * 1000 * \sigma \mathbf{c} *$ 国

\subsection{Results analysis}

Bending stresses and sleeper-ballast contact pressure were considered as the design criterion. These parameters were determined for the proposed models as shown in Table 13 using previous equations to select the preliminary optimal model of sleeper. The results are then compared and checked with their allowable limits as discussed in the following sections.

\subsubsection{Bending stress at rail seat}

From results, it is noted that all proposed models have bending strength at rail seat greater than minimum AREMA recommendation (6.8 MPa) as shown in Figure 26.

\subsubsection{Bending stress at center of sleeper}

From results, it is obvious that the models T9 and T18 have a bending stress greater than minimum AREMA recommendations (13.8 MPa) as shown in Figure 27.

\subsubsection{Contact pressure between sleeper and ballast}

From results, it is obvious that all the models have a contact pressure within the limits of maximum allowable pressure according to AREA recommendations ( $590 \mathrm{KPa}$ ) except model T21 as shown in Figure 28.

\subsection{Selection of the optimal sleeper dimensions}

Selecting the optimum model is based on the criteria mentioned above, the bending stress and the pressure distribution beneath the sleeper. It is found that T9 and T18 which have geometrical properties with $150 \mathrm{~mm}$ depth at center of sleeper and $2400 \mathrm{~mm}$ length is the optimal design. T9 with $230 \mathrm{~mm}$ width is preferred because it has contact pressure between ballast and sleeper lesser than T18. Then, It was decided that the sleeper design with rail seat inclination 1:20 was selected, so the depth of sleeper was designed to be changed from 170 at the end of sleeper to 150 at center of sleeper with average depth $160 \mathrm{~mm}$ at rail seat position as shown in Figure 29 . This proposed design of sleeper was decided to be manufactured to perform recommended laboratory tests on it. Actual manufactured sleeper with proposed design is portrayed in Figure 30.

\section{CONCLUSIONS}

In terms of strength and stiffness according to the comparison of test results with the standard values AREMA and CTA, the material of the proposed innovated sleeper is adequate to sustain the loading conditions of Egyptian National Railways (ENR). The main findings of proposed composite mixture based on testing results can be summarized as follows:

1- The relationship of the stress-strain and values of strain of the proposed material are similar to the behavior of some wooden types that used in manufacturing of railway sleepers. 
2- The proposed composite mixture illustrated linear elastic up to the proportion limit in the compression test.

3- Obtained value of maximum compression stress (perpendicular to grain), $32.08 \mathrm{MPa}$, is larger than the required value by the standards of railways.

4- Obtained value of maximum compression stress (parallel to grain), $36.39 \mathrm{MPa}$, is larger than the required value by the standards of railways.

5- Obtained value of modulus of elasticity (compression), $8581 \mathrm{MPa}$, is larger than the required value by the standards of railways.

6- Obtained value of flexure strength, 22.07 MPa is larger than the required value by the standards of railways.

7- Obtained value for the modulus of elasticity (flexural) is $1519 \mathrm{MPa}$.

8- The proposed composite mixture has a coefficient of linear thermal expansion,2.3E-05 $\mathrm{mm} / \mathrm{mm} / \mathrm{C}^{0}$ which is less than recommended values of standards of railways.

9- Selection of the optimal model of sleeper dimensions to be manufactured based on evaluation of 21 proposed models with different dimensions.

However; samples of full scale sleepers should be tested in static and dynamic conditions; hence the results should be compared with AREMA and ENR standards.

\section{Acknowledgment}

The authors gratefully acknowledge the support provided by staff of Properties of Materials and Quality Control Lab, Shoubra Faculty of Engineering.

\section{References}

1. Esveld, C. Modern Railway Track. MRT-Productions, the Netherlands; 2001. pp 201.

2. Ellis Dc. Track Terminology. British railway track, the permanent way, Institution, England; 2001.

3. ENR . Railway Track Guidelines. Egypt, 2002.

4. CIC Innovation Consultants Inc. A Custom Market Research Study reviewing The Potential For: Plastic Railroad Ties in Canada. Environmental and Plastics Industry Council; 2003.

5. Smith, S.T. Economics of treated wood used in aquatic applications. Report prepared for the Western Wood Preservers Institute; 2006. http://www.wwpinstitute.org/ [Viewed 16 August 2015]

6. Zarembski, A.M. Concrete vs. wood ties: Making the economic choice. Conference on Maintaining Railway Track: Determining Cost and Allocating Resources, Arlington, VA, 1993.

7. Lampo, R., T. Pinnick, and T. Nosker. Development, Testing, and Demonstration of Recycled-Plastic Composite RR Crossties. US army engineer research and development center, champaign, Illinois ; 2000.

8. Hagaman, B.R. \&McAlpine, R.J.A., ROA Timber Sleeper Development Project. Railway Engineering Conference, Adelaide, 1991. pp 233-237.

9. Anne \& Russ Evans. Rubber/Plastic Composite Rail Sleepers. Published by: The Waste \& Resources Action Program; 2006.

10. Bank, L.C. Composites for construction: Structural design with FRP materials. John Wiley and Sons, Inc., New Jersey; 2006.

11. Doyle, N.F. Railway Track Design: A Review of Current Practice. Occasional Paper No. 35. Bureau of Transport Economics, Commonwealth of Australia, Canberra; 1980.

12. Sadeghi, J. \&Barati, P. Evaluation of conventional methods in Analysis and Design of Railway Track System. International Journal of Civil Engineering, Vol. 8, No.1; 2010.

13. Sadeghi, J., and Yoldashkhan, M. Investigation on the accuracy of current practices in analysis of railway track sleepers. International Journal of Civil Engineering, Vol. 3, No. 1, pp. 9-15; 2005.

14. Barati, P., Sadeghi, J. Comparisons of Mechanical Properties of Timber, Steel and Concrete Sleepers. Journal of Structure and Infrastructure Engineering. 2010. 
15. Khalil, A. A. Mechanical testing of innovated composite polymer material for using in manufacture of railway sleepers. Journal of polymers and the environment, Springer. 2017.

16. American Society for Testing and Materials, D6108-97, D6109-97, D6111-03, D696- 03, USA; 2013.

17. Gupta, R. Composite Sleepers: an Environment Friendly Alternate Sleeper for Track and bridges. Forest products journal; 2003, 55(12), pp 29-34.

18. AREMA Manual for Railway Engineering - Chapter 30, American Railway Engineering and Maintenance-of-Way Association, Maryland, USA. 2010.

Table 1 : Recommended relationship for dynamic coefficient factors [12]

\begin{tabular}{|c|c|}
\hline Recommender & Relation \\
\hline AREA & $\phi=1+5.21 \frac{V}{D}$ \\
\hline E1senmann & $\phi=1+\delta \eta t$ \\
\hline ORE & $\phi=1+\alpha^{\prime}+\beta^{\prime}+\gamma^{\prime}$ \\
\hline DB & $\phi=1+\frac{V^{2}}{30000}{ }^{\prime} \varphi=1+\frac{4.5 \mathrm{~V}^{2}}{10^{3}}-\frac{1.5 \mathrm{~V}^{3}}{10^{7}}$ \\
\hline BR & $\phi=\frac{8.784\left(\alpha_{1}+\alpha_{2}\right) V}{P}\left[\frac{D_{j} P_{u}}{g}\right]^{1 / 2}$ \\
\hline India & $\phi=1+\frac{V}{58.14 k^{0.5}}$ \\
\hline South Africa & $\phi=1+4.92 \frac{V}{D}$ \\
\hline CA & $\phi=1+\frac{19.65 V}{D K}$ \\
\hline WMMTA & $\phi=\left(1+3.86^{*} 10^{-5} \mathrm{~V}^{2}\right)^{0.67}$ \\
\hline SADEGHI & $\phi=1.098+8 \times 10^{-4} V+10^{-6} V^{2}$ \\
\hline
\end{tabular}

Table 2 : Relations for the calculation of maximum rail seat load [12].

\begin{tabular}{|c|c|}
\hline Maximum rail seat load (KN) & Methods \\
\hline $\mathrm{q}_{\mathrm{r}}=0.5 \mathrm{p}$ & Three adjacent sleepers method \\
\hline $\mathrm{q}_{\mathrm{r}}=0.43 \mathrm{p}$ & Australian Formula [ARS] \\
\hline $\mathrm{q}_{\mathrm{r}}=0.6 \mathrm{p}$ & AREA method \\
\hline $\mathrm{q}_{\mathrm{r}}=0.65 \mathrm{p}$ & ORE method \\
\hline
\end{tabular}


"ANALYSIS ON RAILWAY SLEEPERS MANUFACTURED FROM POLYMERS AND IRON SLAG"

Table 3: Relations for the bending moment calculation [13].

\begin{tabular}{|c|c|c|c|c|c|}
\hline \multicolumn{2}{|c|}{ Center moment } & \multicolumn{2}{|c|}{ Rail seat moment } & \multirow{2}{*}{ Developer } & \multirow{2}{*}{$\begin{array}{c}\text { Sleeper } \\
\text { Type }\end{array}$} \\
\hline $\mathrm{M}_{\mathrm{r}}^{-}(\mathrm{KN} . \mathrm{m})$ & $\mathrm{M}_{\mathrm{r}}^{+}$(KN.m) & $\mathrm{M}_{\mathrm{r}}^{-}(\mathrm{KN} . \mathrm{m})$ & $\mathrm{M}_{\mathrm{r}}^{+}(\mathrm{KN} . \mathrm{m})$ & & \\
\hline $\operatorname{qr}\left(\frac{g}{2}\right)$ & -------- & ---------- & $\operatorname{qr}\left(\frac{l-g}{2}\right)$ & Battelle & \\
\hline ------- & ------- & -------- & $\operatorname{qr}\left(\frac{l-g-j}{8}\right)$ & Scharmm & Timber \\
\hline $\operatorname{qr}\left(\frac{2 g-l}{4}\right)$ & -------- & -------- & -- & Raymond & \\
\hline $\operatorname{qr}\left(\frac{2 g-l}{4}\right)$ & $0.05 \times \mathrm{qr} \times(-g)$ & ------- & $q r\left(\frac{l-g}{8}\right)$ & $\begin{array}{c}\text { Austrailian } \\
\text { standard }\end{array}$ & Steel \\
\hline $\operatorname{qr}\left(\frac{2 g-l}{4}\right)$ & $0.05 \times \mathrm{qr} \times(-g)$ & $\begin{array}{l}\operatorname{Max}\{0.67 \\
\left.\mathrm{Mr}_{\mathrm{r}}^{+}, 14\right\}\end{array}$ & $\operatorname{qr}\left(\frac{l-g}{8}\right)$ & $\begin{array}{c}\text { Austrailian } \\
\text { standard }\end{array}$ & Concrete \\
\hline
\end{tabular}

Table 4 : Trials of composite mixture

(Note: the following materials percentages represent percentages of total mixture weight expect cobalt and

\begin{tabular}{|c|c|c|c|c|c|c|c|c|}
\hline \multicolumn{9}{|c|}{ MEKP) } \\
\hline $\begin{array}{c}\text { Fiber } \\
\text { distribution }\end{array}$ & $\begin{array}{c}\text { Fiber } \\
\text { distribution } \\
\text { illustration }\end{array}$ & $\begin{array}{c}\text { Styrene } \\
\%\end{array}$ & $\begin{array}{l}\text { Polyester } \\
\text { resin \% }\end{array}$ & $\begin{array}{c}\mathrm{CaCo3} \\
\%\end{array}$ & $\begin{array}{c}\text { Steel } \\
\text { slag } \\
\%\end{array}$ & $\underset{\%}{\text { RHDPE }}$ & Mix & Group \\
\hline \multirow{2}{*}{$\begin{array}{l}\text { Equally along depth } \\
\text { of specimen }\end{array}$} & \multirow{2}{*}{ m } & - & 58 & 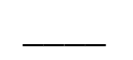 & 21 & 21 & $\mathrm{~S} 1$ & \multirow{2}{*}{$\stackrel{0}{0}$} \\
\hline & & & 52 & & 24 & 24 & $\mathrm{~S} 2$ & \\
\hline $\begin{array}{l}\text { Equally along depth } \\
\text { of specimen }\end{array}$ & 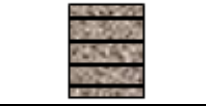 & 9 & 43 & & 24 & 24 & S4 & \multirow{4}{*}{ ڤ̂̉ } \\
\hline $\begin{array}{l}\text { Equally along depth } \\
\text { of specimen }\end{array}$ & $\Leftrightarrow$ & 9 & 43 & & 24 & 24 & S4w & \\
\hline $\begin{array}{l}\text { Equally along depth } \\
\text { of specimen }\end{array}$ & ma & 9 & 32 & 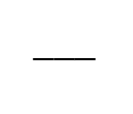 & 35 & 24 & S5 & \\
\hline $\begin{array}{l}\text { Equally along depth } \\
\text { of specimen }\end{array}$ & m & 15 & 26 & & 35 & 24 & S6 & \\
\hline $\begin{array}{l}\text { Equally along depth } \\
\text { of specimen }\end{array}$ & ma & - & 50 & 10 & 20 & 20 & S1c & \multirow{4}{*}{ 泀 } \\
\hline $\begin{array}{c}2 \text { compacted layers } \\
\text { at bottom and one at } \\
\text { upper }\end{array}$ & & - & 48 & 14 & 18 & 20 & S8 & \\
\hline $\begin{array}{c}3 \text { compacted layers } \\
\text { at bottom and one at } \\
\text { upper }\end{array}$ & & - & 48 & 14 & 18 & 20 & S7 & \\
\hline $\begin{array}{l}2 \text { compacted layers } \\
\text { at bottom and one at } \\
\text { upper }\end{array}$ & 四四 & & 44 & 18 & 18 & 20 & S10 & \\
\hline
\end{tabular}


"ANALYSIS ON RAILWAY SLEEPERS MANUFACTURED FROM POLYMERS AND IRON SLAG"

\begin{tabular}{|c|c|c|c|c|c|c|c|c|}
\hline $\begin{array}{c}3 \text { compacted layers } \\
\text { at bottom and one } \\
\text { layer at upper }\end{array}$ & 要国 & 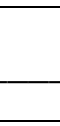 & 44 & 18 & 18 & 20 & S11 & \\
\hline $\begin{array}{l}\text { Equally along depth } \\
\text { of specimen }\end{array}$ & 要学 & 8 & 38 & 10 & 22 & 22 & $\mathrm{~S} 4 \mathrm{c}$ & \\
\hline $\begin{array}{c}3 \text { compacted layers } \\
\text { at bottom and one } \\
\text { upper }\end{array}$ & 票圈 & 5 & 35 & 20 & 20 & 20 & S14 & ổ \\
\hline $\begin{array}{c}3 \text { laminates at } \\
\text { bottom and one } \\
\text { upper }\end{array}$ & & 5 & 35 & 20 & 20 & 20 & S16 & \\
\hline
\end{tabular}

Table 5 : AREMA and CTA composite sleepers' standards [17]

\begin{tabular}{|c|c|c|}
\hline AREMA Standards & $\begin{array}{l}\text { Chicago Transit Authority } \\
\text { (CTA) specifications }\end{array}$ & Mechanical Properties/ Test Method \\
\hline $0.000135 \mathrm{~mm} / \mathrm{mm} \cdot \mathrm{C}^{0}(\operatorname{Max})$ & $0.000126 \mathrm{~mm} / \mathrm{mm} \cdot \mathrm{C}^{0}(\mathrm{Max})$ & $\begin{array}{l}\text { Coefficient of Thermal Expansion } \\
\text { (ASTM D696-98) }\end{array}$ \\
\hline & 20.68 MPa (Min.) & $\begin{array}{l}\text { Compressive Strength ASTM D6108-97 } \\
\text { (Compression Parallel to Grain) }\end{array}$ \\
\hline 6.2 MPa (Min.) & 6.8 MPa (Min.) & $\begin{array}{c}\text { Rail Seat Compression Perpendicular to } \\
\text { Grain ASTM D6108-97 }\end{array}$ \\
\hline $1172 \mathrm{MPa}$ (Min.) & $1172 \mathrm{MPa}$ (Min.) & $\begin{array}{c}\text { Modulus of Elasticity (Compression) } \\
\text { ASTM D6108-97 }\end{array}$ \\
\hline 13.8 MPa (Min.) & 17.23 MPa (Min.) & Flexural Strength ASTM D6109-97 \\
\hline $1172 \mathrm{MPa}$ (Min.) & $1379 \mathrm{MPa}$ (Min.) & $\begin{array}{c}\text { Modulus of Elasticity (Flexural) ASTM } \\
\text { D6109-97 }\end{array}$ \\
\hline
\end{tabular}

Table 6 : Compressive strength results of composite mixtures

\begin{tabular}{|c|c|c|c|c|c|}
\hline $\begin{array}{c}\text { Average } \\
\text { compressive } \\
\text { strength (MPa) }\end{array}$ & $\begin{array}{l}\text { Compressive } \\
\text { strength (MPa) }\end{array}$ & $\begin{array}{c}\text { Compressive load } \\
(\mathrm{KN})\end{array}$ & $\begin{array}{l}\text { Density } \\
\mathrm{Kg} / \mathrm{m}^{3}\end{array}$ & & Group \\
\hline \multirow{3}{*}{31.91} & 33.73 & 506 & \multirow{3}{*}{1210} & S1-1 & \multirow{6}{*}{ 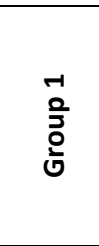 } \\
\hline & 29.00 & 435 & & S1-2 & \\
\hline & 33.00 & 495 & & S1-3 & \\
\hline \multirow{3}{*}{27.11} & 27.53 & 413 & \multirow{3}{*}{1250} & s2-1 & \\
\hline & 27.00 & 405 & & S2-2 & \\
\hline & 26.80 & 402 & & S2-3 & \\
\hline \multirow{3}{*}{26.48} & 27.40 & 411 & \multirow{3}{*}{1230} & S4-1 & \multirow{8}{*}{$\begin{array}{l}\text { N } \\
\text { oำ } \\
\text { ơ }\end{array}$} \\
\hline & 25.33 & 380 & & S4-2 & \\
\hline & 26.73 & 401 & & S4-3 & \\
\hline \multirow{3}{*}{25.71} & 26.40 & 396 & \multirow{3}{*}{1250} & S4w-1 & \\
\hline & 25.33 & 380 & & Sw-2 & \\
\hline & 25.40 & 381 & & Sw-3 & \\
\hline \multirow{2}{*}{23.70} & 24.66 & 370 & \multirow{2}{*}{1640} & S5-1 & \\
\hline & 21.33 & 320 & & S5-2 & \\
\hline
\end{tabular}


"ANALYSIS ON RAILWAY SLEEPERS MANUFACTURED FROM POLYMERS AND IRON SLAG"

\begin{tabular}{|c|c|c|c|c|c|}
\hline & 25.13 & 377 & & S5-3 & \multirow{11}{*}{$\begin{array}{l}m \\
\frac{0}{3} \\
0 \\
\text { 인 }\end{array}$} \\
\hline \multicolumn{4}{|c|}{ failed } & S6 & \\
\hline \multirow{3}{*}{28.28} & 30.20 & 453 & \multirow{3}{*}{1230} & S1c-1 & \\
\hline & 27.20 & 408 & & S1c-2 & \\
\hline & 27.46 & 412 & & S1c-3 & \\
\hline \multirow{3}{*}{30.95} & 30.40 & 456 & \multirow{3}{*}{1370} & S8-1 & \\
\hline & 31.66 & 475 & & S8-2 & \\
\hline & 30.80 & 462 & & S8-3 & \\
\hline \multirow{3}{*}{31.73} & 32.93 & 494 & \multirow{3}{*}{1410} & S10 -1 & \\
\hline & 30.66 & 460 & & S10-2 & \\
\hline & 31.60 & 474 & & S10-3 & \\
\hline \multirow{3}{*}{29.86} & 30.00 & 450 & \multirow{3}{*}{1350} & S4c -1 & \multirow{6}{*}{$\begin{array}{l}\text { 寸 } \\
\text { 윽 } \\
\text { 인 }\end{array}$} \\
\hline & 29.93 & 449 & & S4c-2 & \\
\hline & 29.66 & 445 & & S4c-3 & \\
\hline \multirow{3}{*}{32.08} & 31.33 & 470 & \multirow{3}{*}{1430} & S16 -1 & \\
\hline & 33.00 & 495 & & S16-2 & \\
\hline & 31.93 & 479 & & S16-3 & \\
\hline
\end{tabular}

Table 7 : Compressive modulus of elasticity of composite mixtures

\begin{tabular}{|c|c|c|c|c|}
\hline $\begin{array}{l}\text { Average compressive } \\
\text { strength }(\mathrm{MPa})\end{array}$ & Average & $\begin{array}{c}\text { Modulus of Elasticity } \\
\text { (MPa) }\end{array}$ & Mix & Group \\
\hline 31.91 & 9807 & 9807 & S1-2 & \multirow{2}{*}{ - } \\
\hline 27.11 & 10297 & 10297 & S2-1 & \\
\hline \multirow{2}{*}{26.48} & \multirow{2}{*}{3432} & 3187 & S4-1 & \multirow{6}{*}{ 光 } \\
\hline & & 3677 & S4-2 & \\
\hline \multirow{3}{*}{25.71} & \multirow{3}{*}{2124} & 1961 & S4w-1 & \\
\hline & & 2451 & S4w-2 & \\
\hline & & 1961 & S4w-3 & \\
\hline 23.70 & 3427 & 3427 & S5-3 & \\
\hline 28.28 & 8825 & 8825 & S1c-1 & \multirow{5}{*}{ ڤે } \\
\hline \multirow{2}{*}{30.95} & \multirow{2}{*}{7992.5} & 7453 & S8-1 & \\
\hline & & 8532 & S8-2 & \\
\hline \multirow{2}{*}{31.73} & \multirow{2}{*}{8090.5} & 8826 & S10 -1 & \\
\hline & & 7355 & S10-2 & \\
\hline 29.86 & 7355 & 7355 & S4c - 1 & \multirow{3}{*}{$\stackrel{0}{0}+$} \\
\hline \multirow{2}{*}{32.08} & \multirow{2}{*}{8581} & 8826 & S16-1 & \\
\hline & & 8336 & S16-2 & \\
\hline
\end{tabular}

Table 8 : Flexural strength results for composite mixtures

\begin{tabular}{|c|c|c|c|c|c|c|}
\hline $\begin{array}{c}\text { Average } \\
\text { flexural } \\
\text { strength } \\
(\mathrm{MPa}) \\
\end{array}$ & $\begin{array}{c}\text { Flexural } \\
\text { strength } \\
\text { (MPa) }\end{array}$ & $\begin{array}{c}\text { Effective } \\
\text { length }(\mathrm{L}) \\
\text { mm }\end{array}$ & $\begin{array}{c}\text { Flexural } \\
\text { load ( P) } \\
(\mathrm{KN})\end{array}$ & $\begin{array}{c}\text { Fiber } \\
\text { illustration }\end{array}$ & Mix & Groups \\
\hline \multirow{2}{*}{15.34} & 18.41 & 450 & 40.92 & \multirow{4}{*}{$\begin{array}{ll}5 \mathrm{sin} \\
\mathrm{Bn}\end{array}$} & S1-1 & \multirow{4}{*}{$\begin{array}{l}-1 \\
\text { 을 } \\
0 \\
0\end{array}$} \\
\hline & 12.27 & 450 & 27.28 & & S1-2 & \\
\hline \multirow{2}{*}{11.06} & 10.8 & 450 & 24 & & s2-1 & \\
\hline & 11.32 & 450 & 25.17 & & S2-2 & \\
\hline \multirow{2}{*}{10.95} & 10.81 & 450 & 24.02 & \multirow{2}{*}{$\Leftrightarrow$} & S4-1 & \multirow{4}{*}{$\begin{array}{l}\text { N } \\
\text { 을 } \\
\text { oㄴํ }\end{array}$} \\
\hline & 11.08 & 450 & 24.63 & & S4-2 & \\
\hline \multirow{2}{*}{21.99} & 21.13 & 450 & 46.97 & \multirow[t]{2}{*}{ 世त्व } & S4w-1 & \\
\hline & 22.85 & 450 & 50.78 & & S4w -2 & \\
\hline \multirow{2}{*}{11.88} & 12.01 & 450 & 26.69 & \multirow[t]{2}{*}{ Bns } & S1c-1 & \multirow{2}{*}{ ث̀ হ } \\
\hline & 11.75 & 450 & 26.11 & & S1c-2 & \\
\hline
\end{tabular}


"ANALYSIS ON RAILWAY SLEEPERS MANUFACTURED FROM POLYMERS AND IRON SLAG"

\begin{tabular}{|c|c|c|c|c|c|c|}
\hline $\begin{array}{c}\text { Average } \\
\text { flexural } \\
\text { strength } \\
\text { (MPa) }\end{array}$ & $\begin{array}{c}\text { Flexural } \\
\text { strength } \\
\text { (MPa) }\end{array}$ & $\begin{array}{c}\text { Effective } \\
\text { length (L) } \\
\text { mm }\end{array}$ & $\begin{array}{c}\text { Flexural } \\
\text { load ( P) } \\
(\mathrm{KN})\end{array}$ & $\begin{array}{c}\text { Fiber } \\
\text { illustration }\end{array}$ & Mix & Groups \\
\hline \multirow{2}{*}{12.21} & 12.41 & 450 & 27.57 & \multirow[t]{2}{*}{ 要用 } & S8-1 & \\
\hline & 12.01 & 450 & 26.69 & & S8-2 & \\
\hline \multirow{2}{*}{13.81} & 13.75 & 450 & 30.57 & \multirow[t]{2}{*}{ 㗐国 } & S7-1 & \\
\hline & 13.86 & 450 & 30.82 & & S7-2 & \\
\hline \multirow{2}{*}{13.34} & 13.14 & 450 & 29.2 & \multirow[t]{2}{*}{ 表望 } & S10 -1 & \\
\hline & 13.55 & 450 & 30.13 & & S10-2 & \\
\hline \multirow{2}{*}{14.15} & 14.01 & 450 & 31.13 & \multirow[t]{2}{*}{ 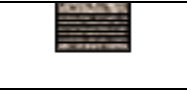 } & S11-1 & \\
\hline & 14.30 & 450 & 31.78 & & S11-2 & \\
\hline \multirow{2}{*}{11.63} & 11.61 & 450 & 25.79 & \multirow[t]{2}{*}{ 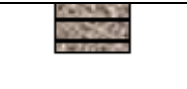 } & S4c -1 & \multirow{6}{*}{$\begin{array}{l}+ \\
0 \\
\frac{0}{3} \\
0 \\
0\end{array}$} \\
\hline & 11.66 & 450 & 25.93 & & S4c-2 & \\
\hline \multirow{2}{*}{20.36} & 20.01 & 450 & 44.47 & \multirow[t]{2}{*}{ 窐葍 } & S14 -1 & \\
\hline & 20.71 & 450 & 46.03 & & S14-2 & \\
\hline \multirow{2}{*}{22.07} & 22.27 & 400 & 55.69 & & S16-1 & \\
\hline & 21.87 & 400 & 54.69 & & S16-2 & \\
\hline
\end{tabular}

Table 9 : Flexural modulus of elasticity for composite mix S16

\begin{tabular}{|c|c|c|c|}
\hline Average & $\begin{array}{c}\text { Modulus of elasticity } \\
(\mathbf{M P a})\end{array}$ & Max load KN & Mix \\
\hline \multirow{2}{*}{1519.82} & 1599.85 & 55.69 & S16-1 \\
\cline { 2 - 4 } & 1439.80 & 54.69 & S16-2 \\
\hline
\end{tabular}

Table 10 : Compressive Strength Parallel to Grain Result.

\begin{tabular}{|c|c|c|c|}
\hline \multirow{2}{*}{ Average } & $\begin{array}{c}\text { Compressive } \\
\text { strength ( MPa) }\end{array}$ & $\begin{array}{c}\text { Compressive } \\
\text { load (KN) }\end{array}$ & Mix \\
\hline \multirow{3}{*}{36.39} & 30.31 & 454.66 & S16-1 \\
\cline { 2 - 4 } & 33.51 & 503.43 & S16-2 \\
\cline { 2 - 4 } & 45.35 & 680.27 & S16-3 \\
\hline
\end{tabular}

Table 11 : Specific gravity and density results.

\begin{tabular}{|c|c|c|c|c|c|}
\hline \multirow{2}{*}{$\begin{array}{c}\text { Density } \\
\mathbf{K g} / \mathbf{m}^{\mathbf{3}}\end{array}$} & $\begin{array}{c}\text { Average of } \\
\text { specific } \\
\text { gravity }\end{array}$ & $\begin{array}{c}\text { Specific } \\
\text { gravity }\end{array}$ & $\begin{array}{c}\text { Net weight of } \\
\text { sample in } \\
\text { water }(\mathbf{K g})\end{array}$ & $\begin{array}{c}\text { Dry weight of } \\
\text { specimen } \\
\text { (Kg) }\end{array}$ & Sample \\
\hline \multirow{3}{*}{1314} & \multirow{2}{*}{1.317} & 1.294 & 0.017 & 0.022 & $\mathbf{S 1 6 - 1}$ \\
\cline { 3 - 6 } & & 1.300 & 0.030 & 0.039 & $\mathbf{S 1 6 - 2}$ \\
\cline { 3 - 6 } & & 1.375 & 0.016 & 0.022 & $\mathbf{S 1 6 - 3}$ \\
\cline { 3 - 6 } & & 1.300 & 0.010 & 0.013 & $\mathbf{S 1 6 - 4}$ \\
\hline
\end{tabular}

Table 12 : Coefficient of Linear Thermal Expansion for Mix S16.

\begin{tabular}{|c|c|c|c|}
\hline \multicolumn{3}{|c|}{ Mix S16 } & \\
\hline \multicolumn{3}{|c|}{150} & Length $\mathrm{mm}$ \\
\hline \multicolumn{3}{|c|}{25} & Thickness mm \\
\hline cold & hot & cold & \multirow{2}{*}{$\operatorname{Temp}\left(c^{0}\right)$} \\
\hline-30 & 30 & -30 & \\
\hline 6.52 & 6.74 & 6.54 & Gage reading $\mathbf{m m}$ \\
\hline \multicolumn{2}{|c|}{ contraction } & expansion & $\Delta t\left(\mathbf{C}^{0}\right)$ \\
\hline \multicolumn{2}{|c|}{-60} & 60 & \\
\hline \multicolumn{2}{|c|}{0.22} & 0.2 & $\Delta \mathbf{L ~ m m}$ \\
\hline \multicolumn{2}{|c|}{$3.6 \mathrm{E}-03$} & $3.3 \mathrm{E}-03$ & $\Delta \mathbf{L} / \Delta \mathrm{t}\left(\mathrm{mm} / \mathbf{C}^{0}\right)$ \\
\hline \multicolumn{2}{|c|}{$2.4 \mathrm{E}-05$} & $2.2 \mathrm{E}-05$ & $\Delta\left(\mathbf{m m} / \mathbf{m m} \cdot \mathrm{C}^{\mathbf{0}}\right)$ \\
\hline \multicolumn{3}{|c|}{ 2.3E-05 mm/mm.C ${ }^{0}$} & CLTE average $(\Delta)$ \\
\hline
\end{tabular}


Table 13 Results of proposed models calculations.

\begin{tabular}{|c|c|c|c|c|c|c|c|c|c|c|c|c|c|}
\hline Sleeper & (1) $\mathrm{mm}$ & (B) $\mathrm{mm}$ & (t) $\mathrm{mm}$ & gauge $(\mathrm{g})$ & (L) $\mathrm{mm}$ & \multicolumn{2}{|c|}{ (qr) KNMax Pa (Kpa) } & $\mathrm{Mr}(\mathrm{KN.m})$ & $\mathrm{Mc}(\mathrm{KNIm})$ & ord Mpa & $\sigma c \mathrm{Mpa}$ & Tmin (rail ser & $\min$ (center) \\
\hline $\mathrm{Tl}$ & 2600 & 230 & 170 & 1520 & 1080 & 76.51 & 511.80 & 10.33 & 8.42 & 9.32 & 7.60 & 173.03 & 118.28 \\
\hline $\mathrm{T} 2$ & 2500 & 230 & 170 & 1520 & 980 & 76.51 & 532.27 & 9.37 & 10.33 & 8.46 & 9.32 & 160.26 & 128.48 \\
\hline $\mathrm{T} 3$ & 2400 & 230 & 170 & 1520 & 880 & 76.51 & 554.45 & 8.42 & 12.24 & 7.60 & 11.05 & 147.24 & 137.05 \\
\hline T4 & 2600 & 230 & 160 & 1520 & 1080 & 76.51 & 511.80 & 10.33 & 8.42 & 10.53 & 8.58 & 173.03 & 118.28 \\
\hline T5 & 2500 & 230 & 160 & 1520 & 980 & 76.51 & 532.27 & 9.37 & 10.33 & 9.55 & 10.53 & 160.26 & 128.48 \\
\hline T6 & 2400 & 230 & 160 & 1520 & 880 & 76.51 & 554.45 & 8.42 & 12.24 & 8.58 & 12.48 & 147.24 & 137.05 \\
\hline T7 & 2600 & 230 & 150 & 1520 & 1080 & 76.51 & 511.80 & 10.33 & 8.42 & 11.98 & 9.76 & 173.03 & 118.28 \\
\hline T8 & 2500 & 230 & 150 & 1520 & 980 & 76.51 & 532.27 & 9.37 & 10.33 & 10.87 & 11.98 & 160.26 & 128.48 \\
\hline T9 & 2400 & 230 & 150 & 1520 & 880 & 76.51 & 554.45 & 8.42 & 12.24 & 9.76 & 14.19 & 147.24 & 137.05 \\
\hline $\mathrm{T} 10$ & 2600 & 220 & 170 & 1520 & 1080 & 76.51 & 535.06 & 10.33 & 8.42 & 9.75 & 7.94 & 173.03 & 118.28 \\
\hline $\mathrm{T} 11$ & 2500 & 220 & 170 & 1520 & 980 & 76.51 & 556.46 & 9.37 & 10.33 & 8.85 & 9.75 & 160.26 & 128.48 \\
\hline $\mathrm{T} 12$ & 2400 & 220 & 170 & 1520 & 880 & 76.51 & 579.65 & 8.42 & 12.24 & 7.94 & 11.55 & 147.24 & 137.05 \\
\hline $\mathrm{T} 13$ & 2600 & 220 & 160 & 1520 & 1080 & 76.51 & 535.06 & 10.33 & 8.42 & 11.00 & 8.97 & 173.03 & 118.28 \\
\hline $\mathrm{T} 14$ & 2500 & 220 & 160 & 1520 & 980 & 76.51 & 556.46 & 9.37 & 10.33 & 9.99 & 11.00 & 160.26 & 128.48 \\
\hline $\mathrm{T} 15$ & 2400 & 220 & 160 & 1520 & 880 & 76.51 & 579.65 & 8.42 & 12.24 & 8.97 & 13.04 & 147.24 & 137.05 \\
\hline $\mathrm{T} 16$ & 2600 & 220 & 150 & 1520 & 1080 & 76.51 & 535.06 & 10.33 & 8.42 & 12.52 & 10.20 & 173.03 & 118.28 \\
\hline $\mathrm{T} 17$ & 2500 & 220 & 150 & 1520 & 980 & 76.51 & 556.46 & 9.37 & 10.33 & 11.36 & 12.52 & 160.26 & 128.48 \\
\hline $\mathrm{T} 18$ & 2400 & 220 & 150 & 1520 & 880 & 76.51 & 579.65 & 8.42 & 12.24 & 10.20 & 14.84 & 147.24 & 137.05 \\
\hline $\mathrm{T} 19$ & 2600 & 210 & 170 & 1520 & 1080 & 76.51 & 560.54 & 10.33 & 8.42 & 10.21 & 8.32 & 173.03 & 118.28 \\
\hline $\mathrm{T} 20$ & 2500 & 210 & 170 & 1520 & 980 & 76.51 & 582.96 & 9.37 & 10.33 & 9.27 & 10.21 & 160.26 & 128.48 \\
\hline $\mathrm{T} 21$ & 2400 & 210 & 170 & 1520 & 880 & 76.51 & 607.25 & 8.42 & 12.24 & 8.32 & 12.10 & 147.24 & 137.05 \\
\hline
\end{tabular}

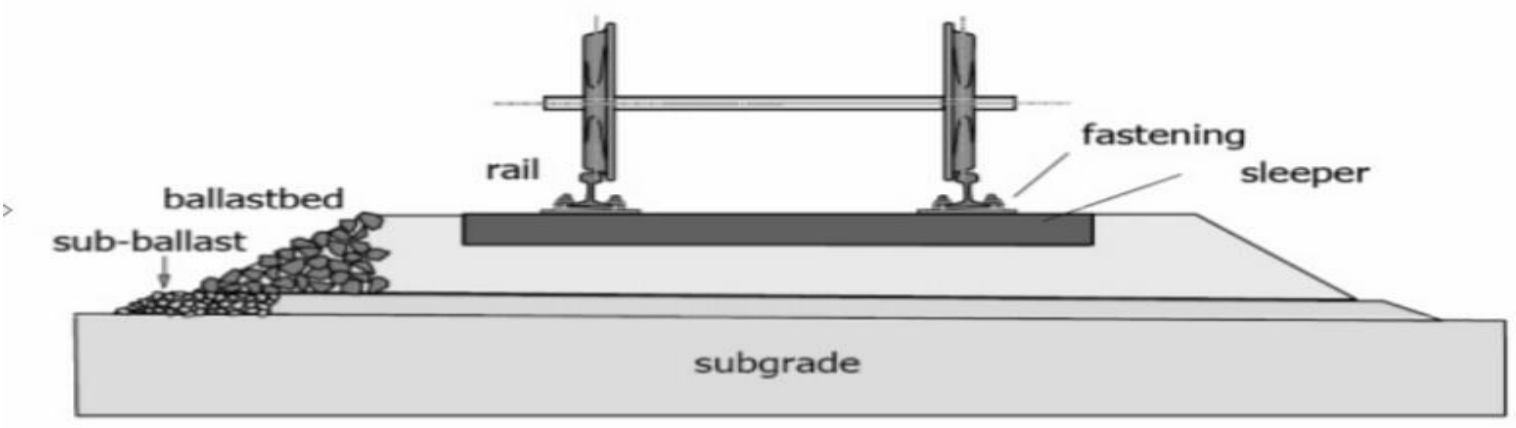

Fig.1. Components of railway track [1].

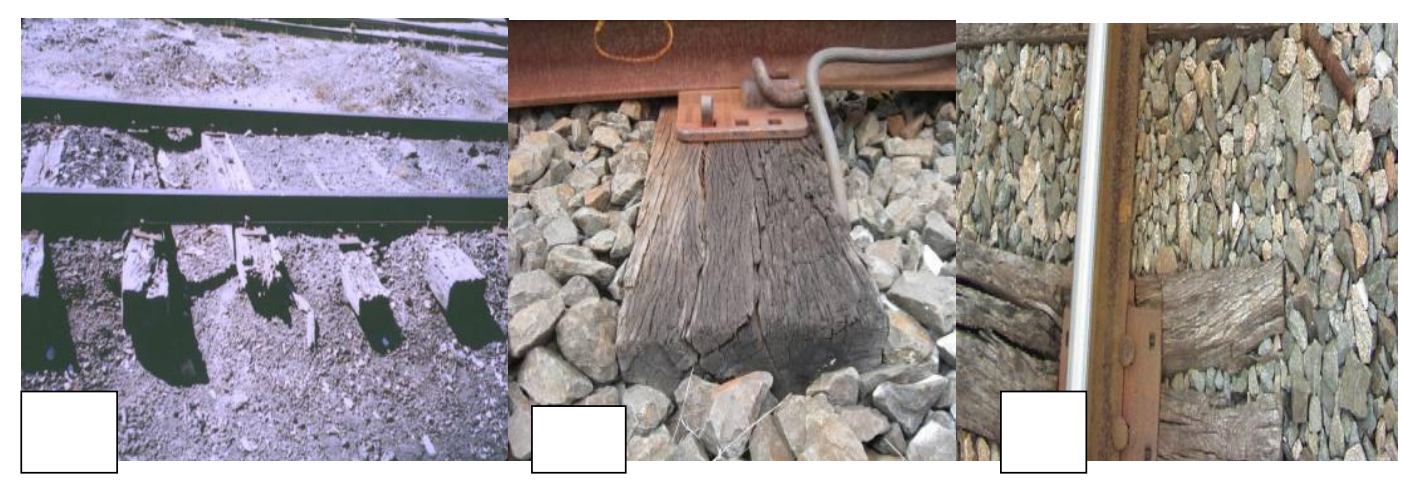

Fig.2. Types of failure modes, (a) Fungal decay [8], b) Splitting at ends [7], c) Spike retention[9] 
"ANALYSIS ON RAILWAY SLEEPERS MANUFACTURED FROM POLYMERS AND IRON SLAG"

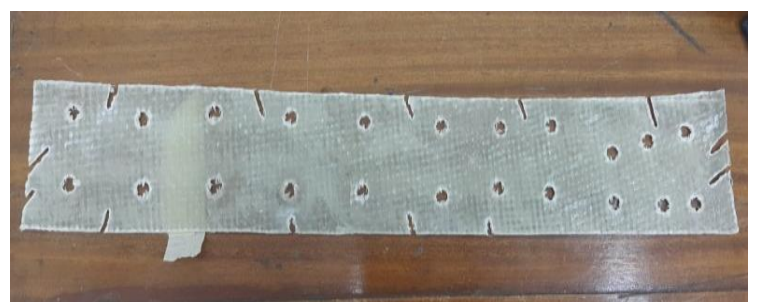

Fig.4. Used laminate in composite mixture

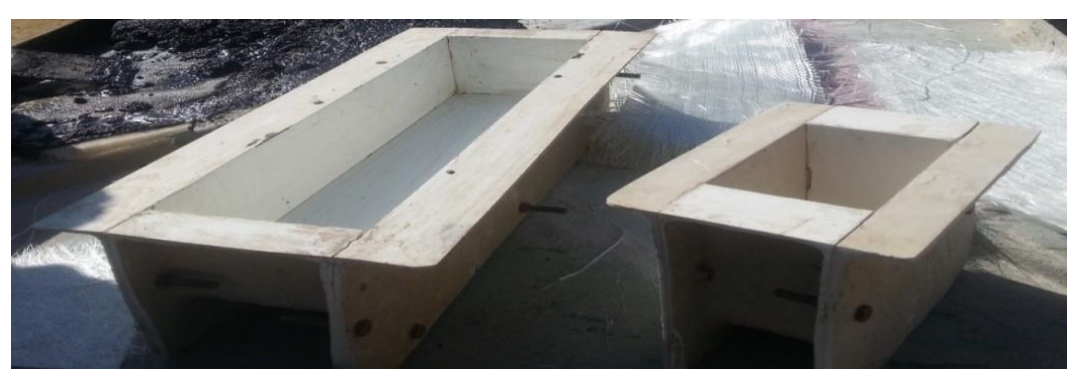

Fig. 5.Cube and Prism Molds [15]

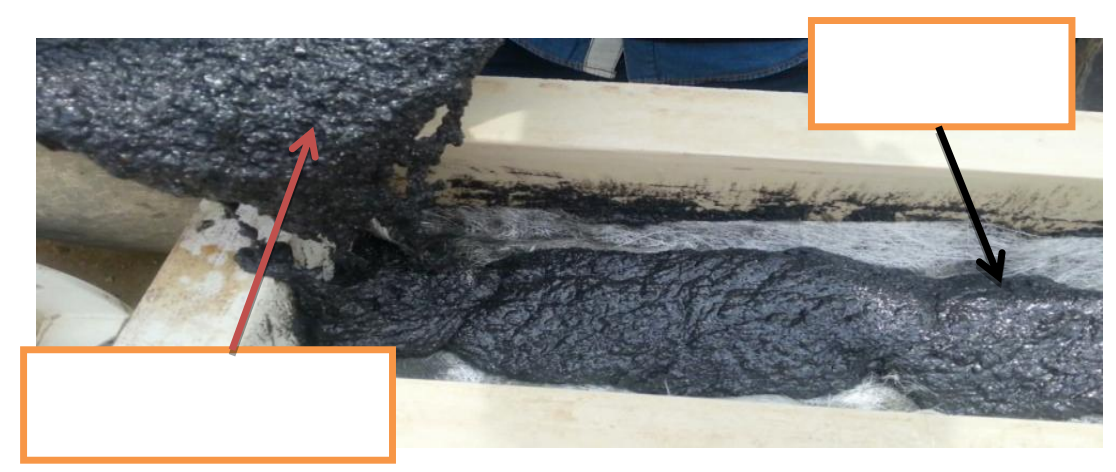

Fig.6. Casting of composite mixture

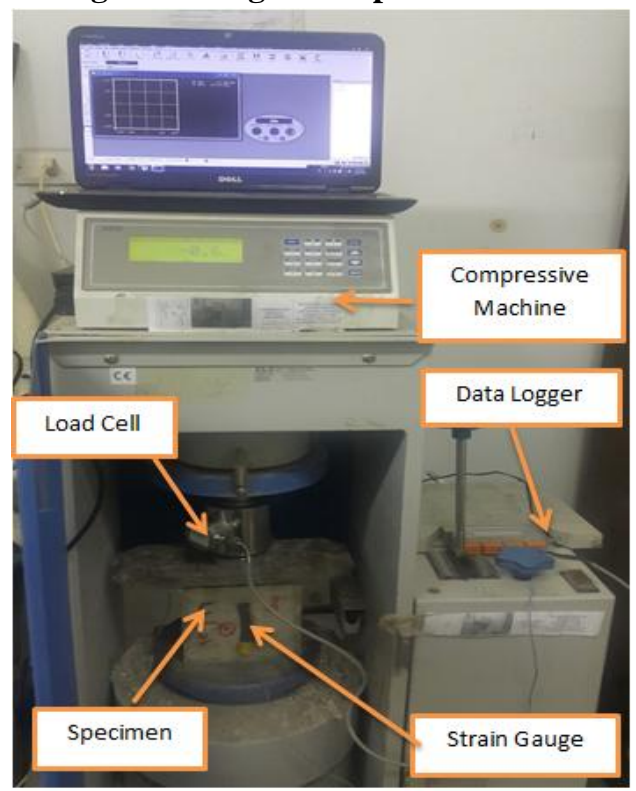

Fig.7. Compressive strength test set up 
"ANALYSIS ON RAILWAY SLEEPERS MANUFACTURED FROM POLYMERS AND IRON SLAG"

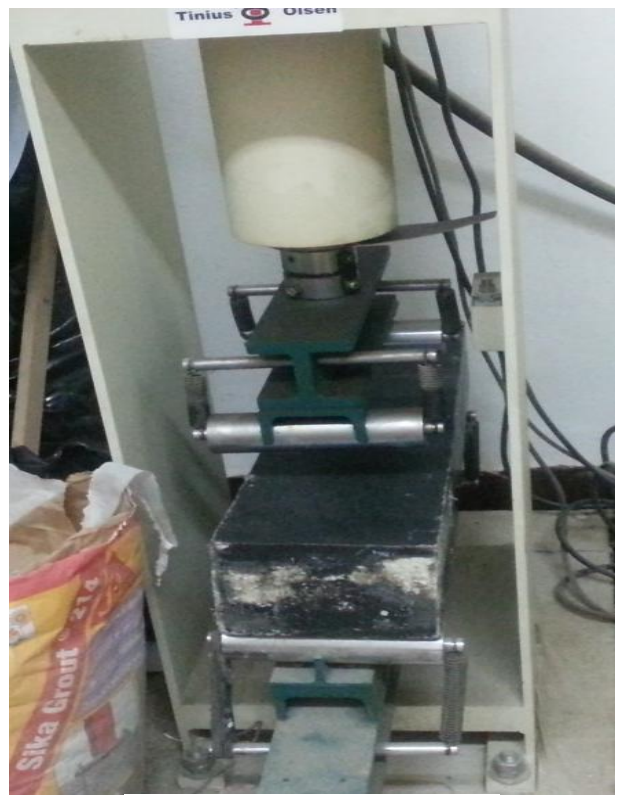

Fig.8. Actual flexural test

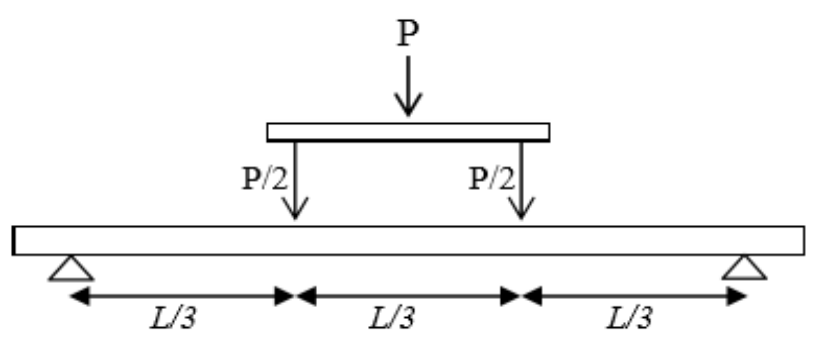

Fig.9. Schematic illustration of flexural test

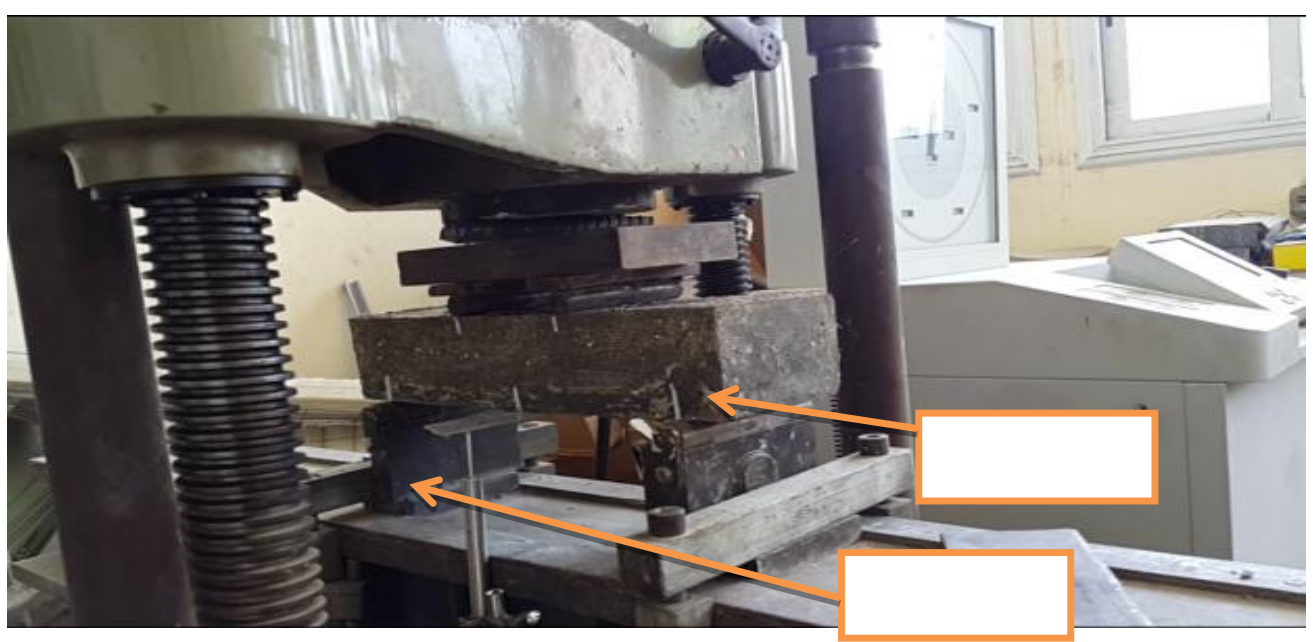

Fig.10. Load -Deflection set up 
"ANALYSIS ON RAILWAY SLEEPERS MANUFACTURED FROM POLYMERS AND IRON SLAG"

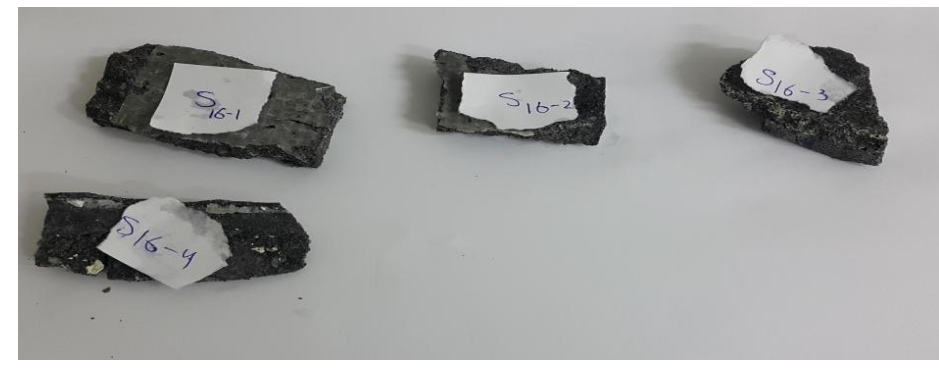

Fig.11. Specimens of specific gravity test

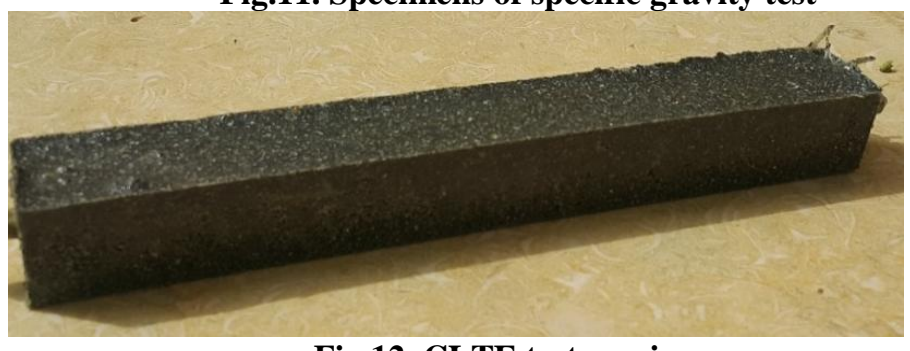

Fig.12. CLTE test specimen

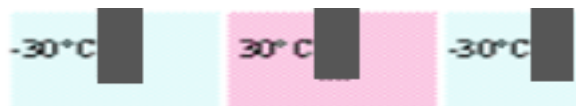

Fig.13.CLTE set up

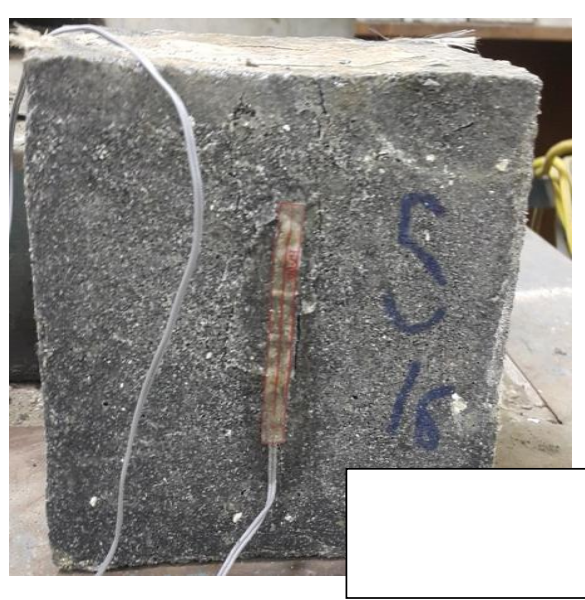

Fig.14.Compressive failure mode of specimen S16

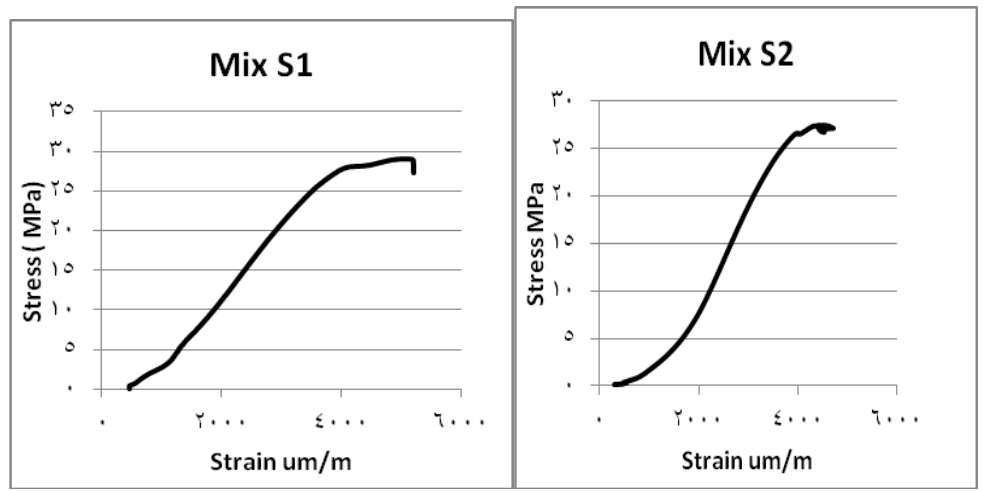

Fig.15. Stress -Strain curve for mix S1

Fig.16. Stress -Strain curve for mix S2 
"ANALYSIS ON RAILWAY SLEEPERS MANUFACTURED FROM POLYMERS AND IRON SLAG"

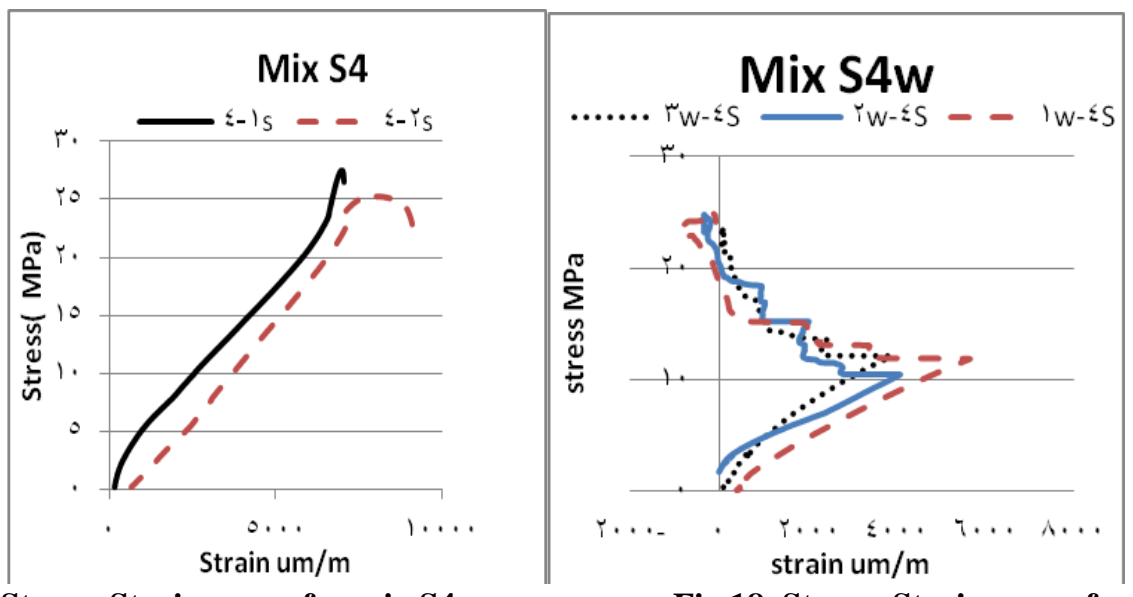

Fig.17.Stress -Strain curve for mix S4

Fig.18. Stress -Strain curve for mix $S 4 w$

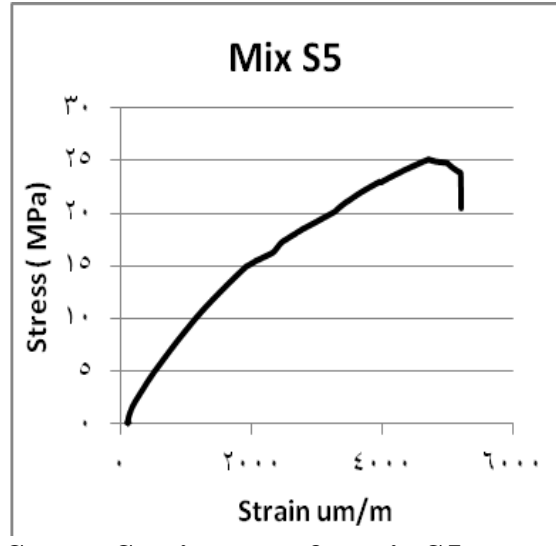

Fig.19.Stress -Strain curve for mix $\mathrm{S5}$

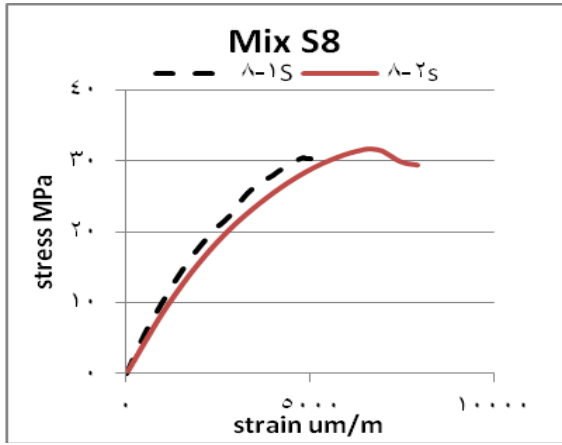

Mix S1c

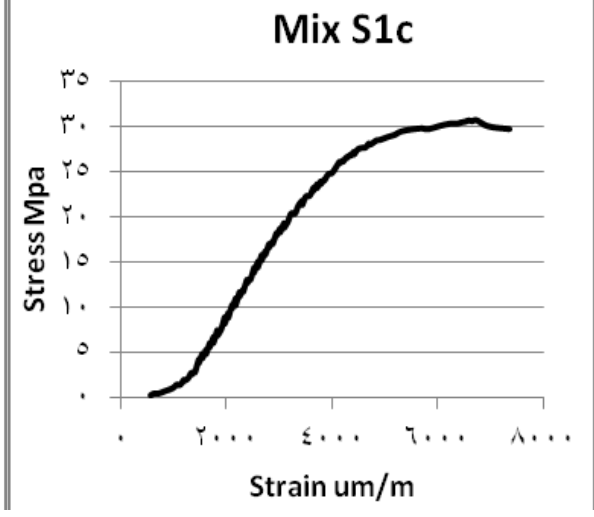

Fig.20.Stress -Strain curve for mix S1C

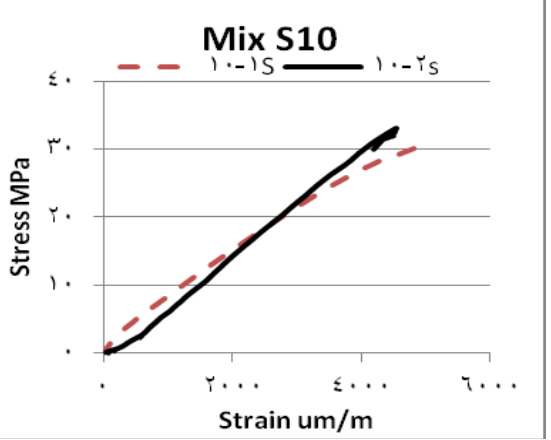

Fig.21. Stress -Strain curve for mix S8Fig. 22. Stress -Strain curve for mix S10

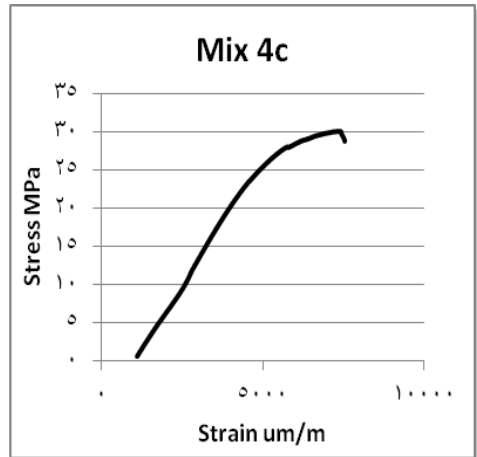

Fig.23.Stress -Strain curve for mix S4

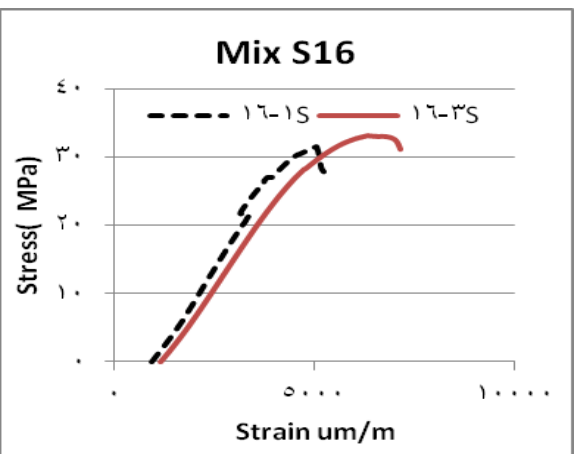

Fig.24. Stress -Strain curve for mix S16 
"ANALYSIS ON RAILWAY SLEEPERS MANUFACTURED FROM POLYMERS AND IRON SLAG"

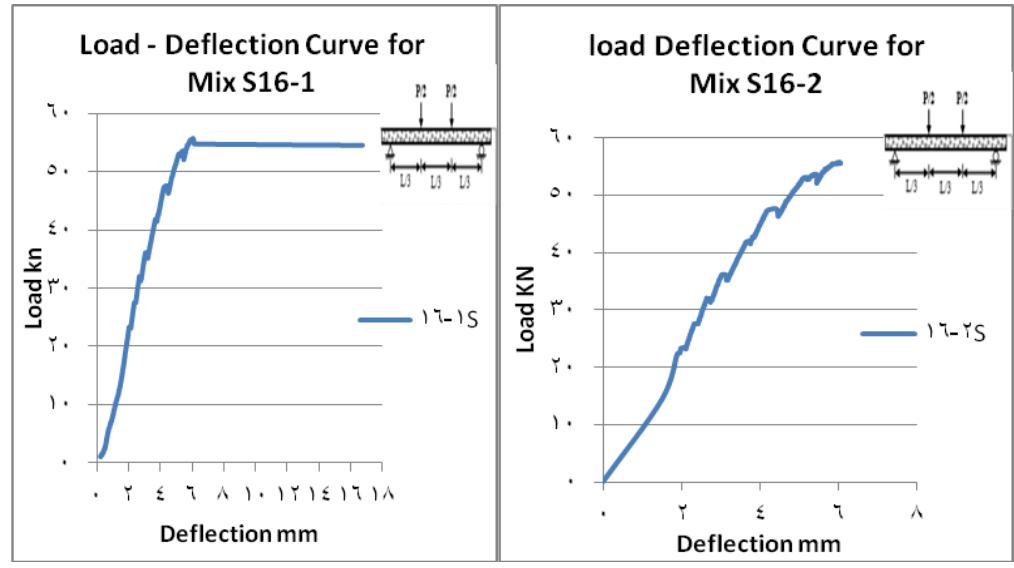

Fig.25. Load- deflection curve for mix S16

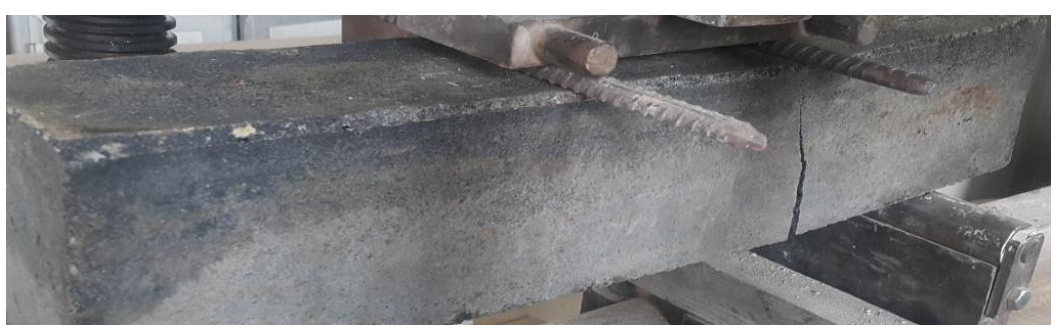

Fig.26. Failure mode of specimen S16

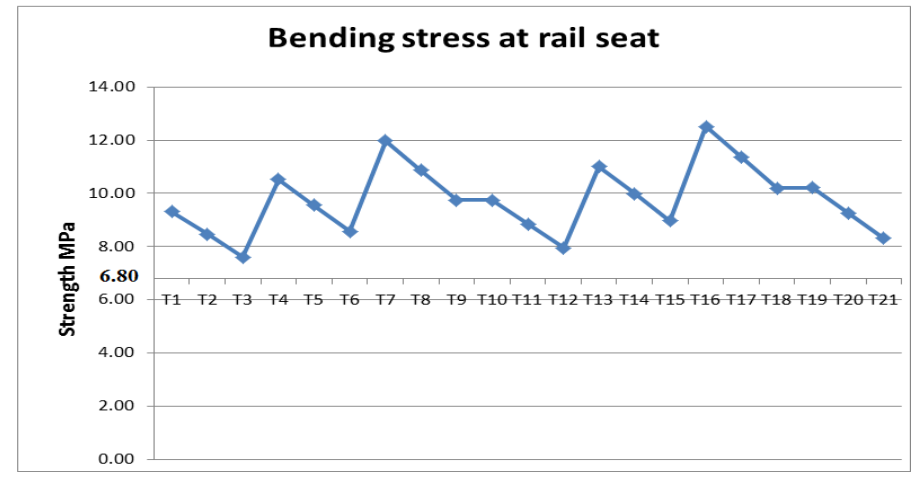

Fig.27 Results of bending stress calculations at rail seat for proposed models

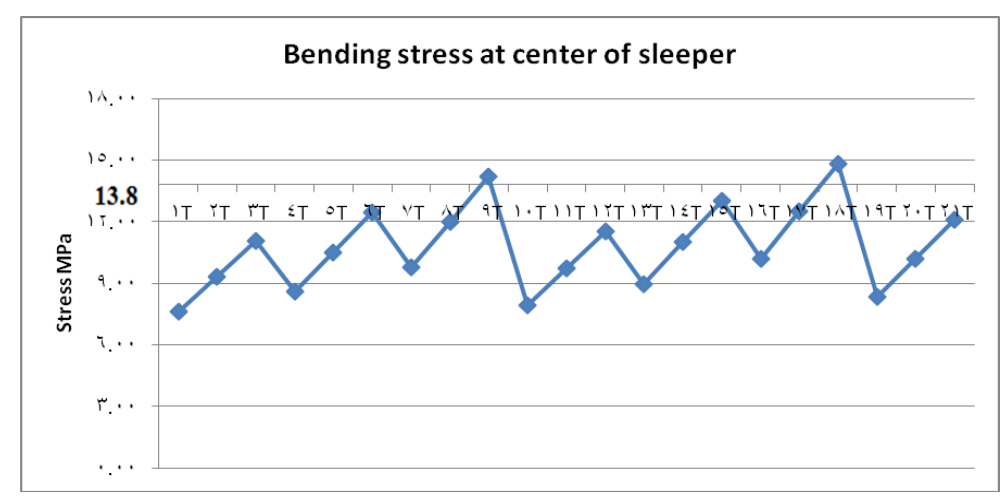

Fig.28 Results of bending stress calculations at the center for proposed model 
"ANALYSIS ON RAILWAY SLEEPERS MANUFACTURED FROM POLYMERS AND IRON SLAG"

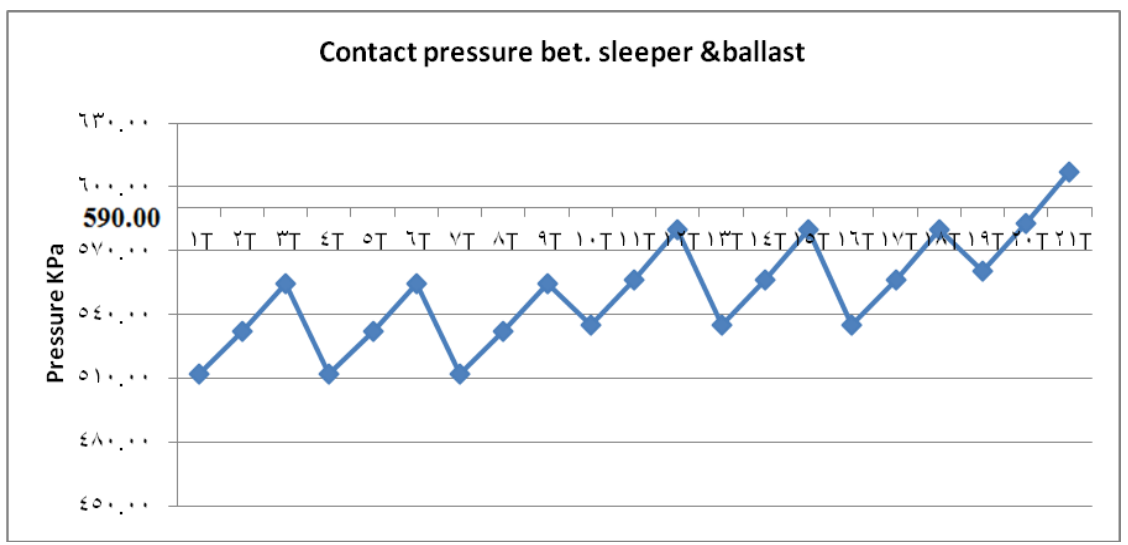

Fig.29 Results of contact pressure calculations between ballast and sleeper for proposed models

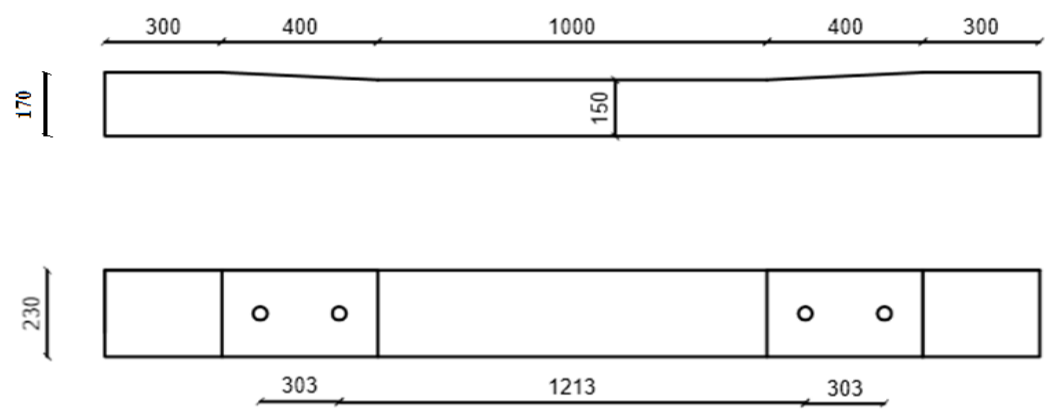

Fig.30 schematic illustration of full scale proposed composite sleeper (all dimensions in mm).

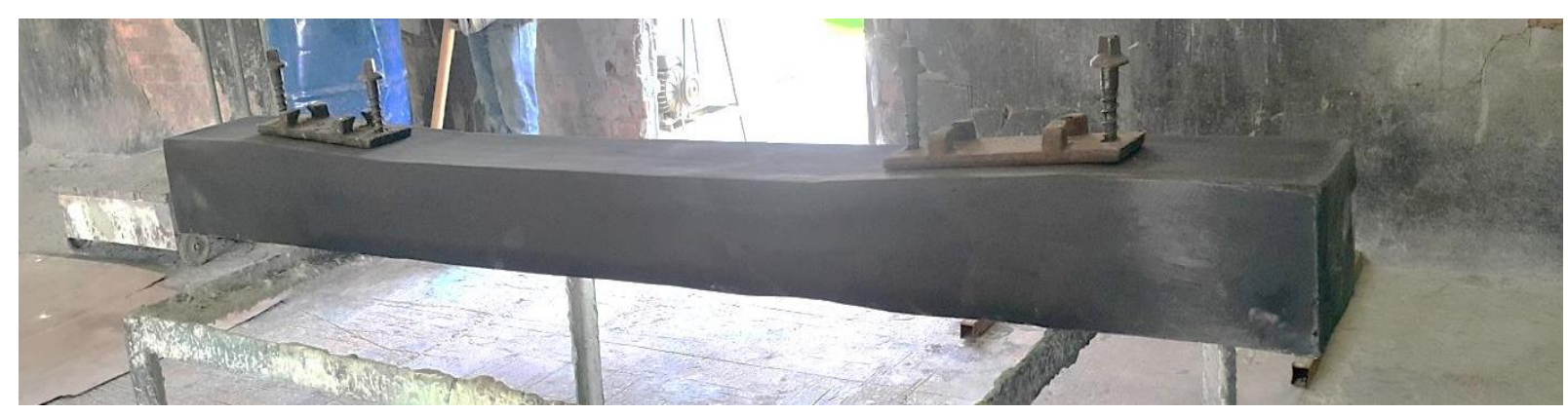

Fig. 31 Actual full scale proposed composite sleeper. 